\title{
A Case of Familial Spontaneous Pneumothorax
}

Fumihiko KAMEZAKI ${ }^{1,2}$, Shinjo SonOda ${ }^{1}$, Shinichiro KOIDE ${ }^{1,2}$ and Yutaka OTSUJI ${ }^{1}$

${ }^{1}$ The Second Department of Internal Medicine, School of Medicine, University of Occupational and Environmental Health, Japan. Yahatanishi-ku, Kitakyushu, 807-8555, Japan

${ }^{2}$ Division of Internal Medicine, Araiyadai Clinic, Japan Atomic Energy Agency, Japan. Tokaimura, Nakagun, 319-1112, Japan

Abstract: We experienced a case of familial spontaneous pneumothorax (SP) without apparent underlying connective tissue disease. A 30-year-old man was referred to our hospital complaining of slight dyspnea and right chest pain due to recurrent SP. The patient had two episodes of primary SP of the right lung, and received chest tube drainage, pleurodesis and surgical bullectomy. Otherwise, his father and two elder sisters also had relapsed primary SP in spite of recurrent prevention therapies. This transmission pattern of the disease phenotype suggested an autosomal dominant inheritance. There have been improvements in pathogenesis, diagnostic procedures and recurrence prevention therapies, but this familial case still suffers from recurrent SP. This familial case may strongly require a new therapeutic strategy for familial SP.

Key words: familial spontaneous pneumothorax, lung cyst, autosomal dominant inheritance.

(Received 2 February 2009, accepted 24 March 2009)

\section{Introduction}

Pneumothorax is a common disorder and defined as the presence of air in the pleural cavity. Pneumothorax occurs without preceding trauma or an obvious precipitating cause and is divided into primary and secondary. Primary spontaneous pneumothorax (SP) arises in patients without clinically apparent lung disease. On the contrary, secondary pneumothorax is associated with underlying lung diseases such as chronic obstructive pulmonary disease, cystic fibrosis and AIDS. Primary SP occurs with an annual incidence of 18-28 per 100,000 population in males and 1.2-6.0 per 100,000 population in females [1]. A history of smoking, 
height, male sex, and family history are known risk factors for primary SP. Most cases of primary SP are sporadic but many familial cases have been reported [2]. Over $10 \%$ of patients with primary SP report a positive family history of the disease. Most of the familial cases are inherited in an autosomal dominant pattern with incomplete penetrance. Recently, mutations in the gene encoding folliculin have been identified in patients with familial SP [2]. Mutations in this gene were known to cause Birt-Hogg-Dubé syndrome (BHDS), which predisposes to the development of multiple lung cysts and SP. Here, we report a familial SP case that has some resemblance to BHDS.

\section{Case Report}

On September, 2008, a 30-year old man was referred to the Araiyadai Clinic complaining of slight dyspnea and right chest pain caused by recurrent SP. The patient was a nonsmoker and had had a first episode of the SP 5 years ago. Chest X-ray showed mild pneumothorax of the right lung, and remission of the affected lung occurred during simple observation. The patient relapsed 4 months after the first event, and was treated by chest tube drainage and pleurodesis via tube drainage in another hospital. Moreover, thoracoscopic bullectomy was performed. The patient was discharged after exclusion of pneumothorax progression and followed up carefully.

The patient had a positive family history of SP: his father and two elder sisters also had episodes of SP (Fig. 1). All of their pneumothoraces were adult onset. His father died from cirrhosis and liver cancer at fifty-five, and his mother from gastric cancer at forty-two. Both his elder sisters could not prevent the recurrences after surgical bullectomy and/or pleurodesis via chest tube drainage. On visit to our clinic, the patient was clinically stable,

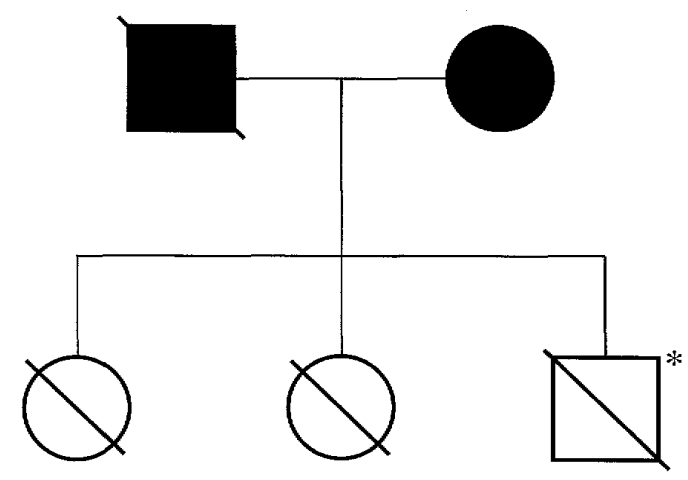

Fig. 1. Pedigree of the family studied.

*: the patient, squares: males, circles: females, slashes: individuals suffering from spontaneous pneumothorax, black symbol: deceased individual. 
although he was suffering from slight dyspnea and right chest pain. The patient's height was $166 \mathrm{~cm}$, weight $70 \mathrm{~kg}$ and height/weight ratio 2.37 . He had no thoracic deformities and no wrist sign. Complete ophthalmological and cardiac examination showed no abnormalities. On lung auscultation, respiratory sound of the right lung was decreased. All other physical examinations were normal. Serum $\alpha_{1}$ antitrypsin was within reference values (121 $\mathrm{mg} / \mathrm{dl}$, normal range: $94-150 \mathrm{mg} / \mathrm{dl}$ ). Chest X-ray showed a right pneumothorax (Fig. 2). According to his decision after informed consent, he was treated by simple manual aspiration. He showed complete re-expansion of the affected lung after 10 days. Helical computed tomography (CT) scan identified cysts and emphysema of the bilateral lungs (Fig. 3). At this

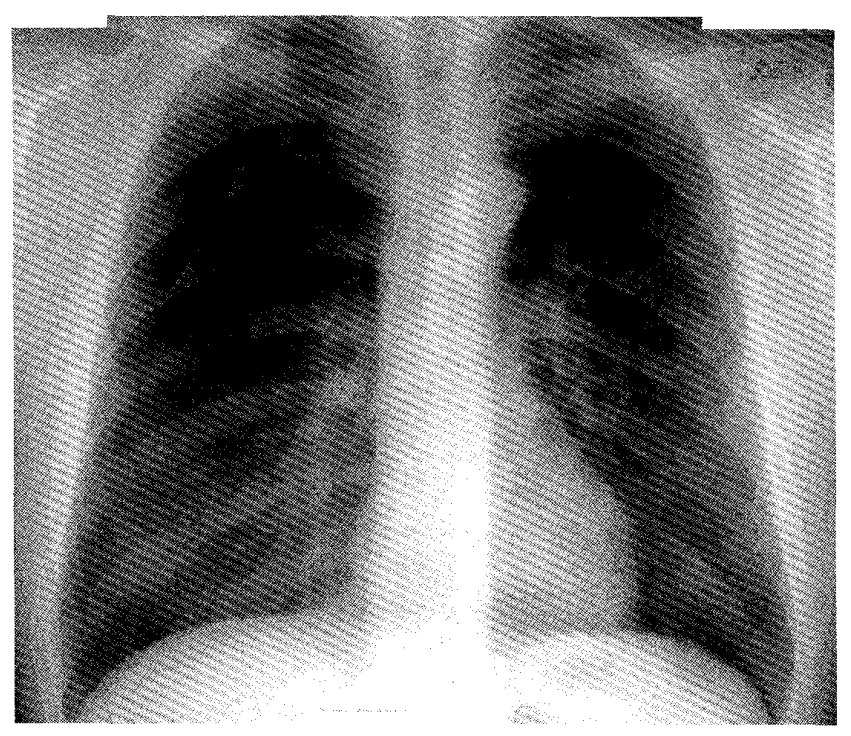

Fig. 2. Chest X-ray showed a right pneumothorax.

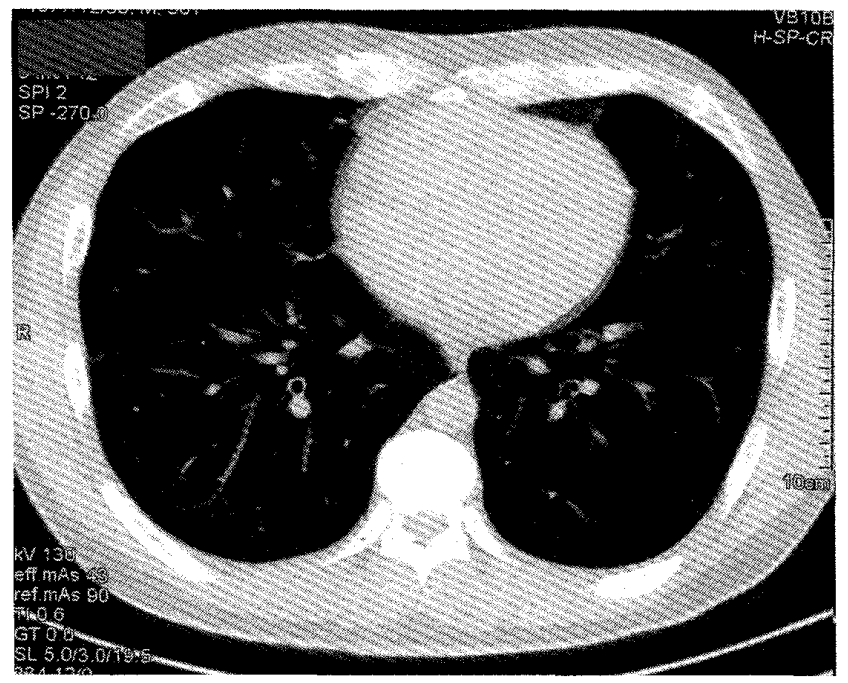

Fig. 3. CT scan identified cysts and emphysema of the bilateral lungs. 
time, he had no skin disorder and no renal cancer, which are atypical for BHDS.

\section{Discussion}

A case of familial SP suspected an autosomal dominant inheritance is reported in this article. Familial SP is a rare disorder, but recently it has been reported that $11.5 \%$ of patients with primary SP have a positive family history of the disease [3]. It may be a complication of various inherited disorders, such as Birt-Hogg-Dubé syndrome (BHDS), $\alpha_{1}$-antitrypsin deficiency, Marfan syndrome, Ehlers-Danlos syndrome, primary lymphangioleiomyomatosis, tuberous sclerosis, Langerhans cell histiocytosis, and cystic fibrosis. In this case, the patient had no convulsive seizure, no apparent underlying connective tissue disease and skin lesion like white spot and seborrheic dermatitis. In addition, serum $\alpha_{1}$ antitrypsin was within reference values. Out of these genetic diseases, this familial case had some resemblance to BHDS. BHDS is an autosomal dominantly inherited disease characterized by benign skin tumors, diverse types of renal cancer, multiple cysts, and SP. Recent the evidence suggests that the presence of thin-walled cysts in basilar and subpleural locations of the lung is a feature of BHDS, and pneumothorax tends to occur during adulthood. In this case, CT scan identified lung cysts in the basilar and subpleural site, and, in addition, the pneumothorax was adult onset. Moreover, it was very unique that all the siblings in this family had multiple lung cysts and SP without skin tumors and renal cancers, because it has been reported that most families with BHDS display reduced penetrance of the pneumothorax phenotype. However, since the skin findings of BHDS generally appear in the fourth decade and become progressively more noticeable with age, and since renal cancer can be a late finding associated with this syndrome, SP may be the only manifestation of BHDS. There were several individuals who were BHDS gene carriers with only the pneumothorax phenotype [4]. Most mutations in BHDS are frameshift or nonsense mutations that are predicted to truncate the BHD protein folliculin [2]. Genetic analysis was needed for a definitive diagnosis of BHDS, but the patient did not desire it.

It is well accepted that the goals of treatment of primary SP are to remove air from the pleural space and to prevent future recurrences [5]. In the first episode of primary SP, randomized controlled trails have proven that observation and simple aspiration are established first-line therapies [6]. Spontaneous air absorption from the pleural space occurs at a rate of approximately $1.25 \%$ of the volume of hemithorax per day. Hence, observation and simple aspiration is the generally accepted treatment in asymptomatic or minimally symptomatic clinically stable patients with small pneumothoraces. In the first recurrence of primary SP, there is good consensus and clinical evidence that recurrence prevention therapy should be proposed [7]. After a first recurrence, the possibility of subsequent recurrences increases significantly, up to $62 \%$ for a second recurrence and $83 \%$ for a third [8]. The high recurrence rate remains a significant clinical problem, although there have been improvements in 
pathogenesis, diagnostic procedures and recurrence prevention therapies, including thoracoscopic surgery and pleurodesis. We could not demonstrate the pathogenesis of the pneumothorax that reoccurred after thoracoscopic bullectomy with pleurodesis. It is very well known that recurrent primary SP is strongly related to smoking in both sexes, but this patient has no smoking habit. The patient had multiple lung cysts revealed by CT scan. It is controversial whether the rupture of lung cysts is always the cause of recurrent pneumothorax, because it has been reported that video thoracoscopy found no more blebs or bullae in recurrent primary SP [9]. However, in BHDS, it has been demonstrated that there is a significant association between lung cysts and SP [10]. Thus, the pathophysiology of primary SP, especially of familial SP, remains poorly understood.

In conclusion, we experienced a case of familial SP which relapsed despite prevention therapy. This case may strongly require a new therapeutic strategy for familial SP. We hope to stimulate further improvements in understanding the pathogenesis, diagnostic procedures and new treatments, including gene therapy.

\section{References}

1. Henry M, Arnold T \& Harvey J (2003): BTS guidelines for the management of spontaneous penumothorax. Thorax 58: 39-52

2. Toro JR, Wei MH, Glenn GM et al (2008): BHD mutations, clinical and molecular genetic investigations of Birt-Hogg-Dubé syndrome: a new series of 50 families and a review of published reports. J Med Genet 45: 321-331

3. Abolnik IZ, Lossos IS, Zlotogora J \& Brauer R (1991): On the inheritance of primary spontaneous pneumothorax. Am J Med Genet 40: 155-158

4. Chiu HT \& Garcia CK (2006): Familial spontaneous pneumothorax. Curr Opin Pulm Med 12: $268-272$

5. Sahn SA \& Heffner JE (2000): Spontaneous pneumothorax. N Engl J Med 342: 868874

6. Noppen M, Alexander P, Driesen P, Slabbynck H \& Vertraeten A (2002): Manual aspiration versus chest tube drainage in first episode of primary spontaneous pneumothorax. A multicenter, prospective, randomized pilot study. Am J Respir Crit Care Med 165: $1240-1244$

7. Falcoz PE, Binquet C, Clement F, Kaili D, Quantin C, Chocron S \& Etievent JP (2003): Manage of the second episode of spontaneous pneumothorax: a decision analysis. Ann Thorac Surg 76: $1843-1848$

8. Tschopp JM, Rami-Porta R, Noppen M \& Astoul P (2006): Management of spontaneous pneumothorax: state of the art. Eur Respir J 28: 637-650

9. Janssen JP, Schramel FMNH, Sutedja TG, Cuesta MA, Oosterhuis WP \& Postmus PE (1995): Videothoracoscopic appearance of first and recurrent pneumothorax. Chest 
108: $330-334$

10. Toro JR, Pautler SE, Stewart L et al (2007): Lung cysts, spontaneous pneumothorax, and genetic associations in 89 families with Birt-Hogg-Dubé syndrome. Am J Respir Crit Care Med 175: 1044- 1053

家族性自然気胸の一例

亀崎 文彦 ${ }^{1,2}$, 園田 信成 ${ }^{1}$, 小出 真一郎 ${ }^{1,2}$, 尾过 豊

产業医科大学 医学部 第二内科学教室

${ }^{2}$ 日本原子力研究開発機構 荒谷台診療所 内科

要 旨：症例は30 歳男性. 再発性自然気胸による軽度呼吸苦および右胸痛を主訴に日本原子 力研究開発機構荒谷台診療所を受診した. 本症例は,これまで右肺の原発性自然気胸 を2 度発症しており,胸腔ドレナージ,胸膜癒着術や外科的ブラ切除術が施行されて いた，その他，母親を除くすべての家族，つまり父親と 2 人の姉妹もまた再発予防治 療を受けたにも関わらず原発性自然気胸を繰り返してきた。この疾患表現型の伝達 様式は, 常染色体優性遺伝を示唆していた。確定診断には遺伝子解析が必要であるが, 現状では確定診断は有効な治潦法に結びつかず,加えて,本症例は遺伝子解析を希望 しなかった，気胸に対する病因の解明，診断技術や再発予防治療に㧍ける進歩は目覚 ましいが,この家族性症例は依然として再発性自然気胸に苦しんでいる。家族性自然 気胸の本症例は, 新規治療指針の必要性を強く示唆している.

キーワード：家族性旨然気胸,肺のう胞, 常染色体優性遺伝.

J UOEH（産業医大誌） 31 （2）: 167-172（2009） 